\title{
Does Sustainability Matter? A Qualitative Study in Tourism Industry
}

\section{Sürdürülebilirlik Farkeder mi? Turizm Endüstrisi’nde Nitel Bir Çalıșma}

\author{
Murak NAZLI, Yaşar Üniversitesi, Türkiye, nazli.murat@gmail.com
}

\begin{abstract}
The main purpose of the study is to analyze the perception of the concept of "sustainability" among undergraduate tourism students in a foundation university in Izmir, Turkey. Structured face to face interviews with 57 respondents revealed that according to 73.7 percent of participants, firms do not pay attention to sustainability in Turkey. However, only 45.6 percent stated that sustainability matters in tourism industry and 24.6 percent said that sustainability is not seen as an essential ingredient for the tourism industry in Turkey. The level of perception of sustainability varies among the respondents and they have different approaches to the concept of sustainability. Specifically, protection of the green environment, cultural, social and society values, natural beauty and recycling outweigh gaining revenue as a firm and having a profitable business. Being innovative and adding value to work is less considered in terms of describing sustainability.
\end{abstract}

\section{Keywords: Sustainability, Tourism and Hospitality, Sustainable Organization}

Özet: Çalışmanın temel amacı İzmir'de bulunan bir vakıf üniversitesinde lisans turizm öğrencileri arasında sürdürülebilirlik kavramının algısın analiz etmektir. Yapılandırllmış yüz yüze görüşmelerde 57 katılımcıdan elde edilen bilgilere dayanarak, yanttlayanların yüzde 73.7 'si Türkiye'de firmalartn sürdürülebilirliğe dikkat etmediklerini belirtmişstir. Nitekim, sadece yüzde 45.6'ya göre, sürdürülebilirlik turizm endüstrisinde önemlidir ve yüzde 24.6'sina göre sürdürülebilirlik Türkiye'de turizm endüstrisi için gerekli bir unsur olarak görülmemektedir. Yanıtlayanların sürdürülebilirlik için algı seviyesi farklllık göstermektedir ve farkl yaklaşımlar mevcuttur. Özellikle, yeşil çevrenin korunması, sosyal ve toplum değerleri, doğal güzellik ve geri dönüşüm konularl, firmanın gelir elde etmesinden ve karl işe sahip olmasindan daha önemli görülmektedir. Inovatif olmak ve yapılan işe değer katmak sürdürülebilirliği tarif etmede daha az dikkate alınmıştır.

Anahtar Kelimeler: Sürdürülebilirlik, Turizm ve Misafirperverlik, Sürdürülebilir Örgüt

\section{Introduction}

In today's information age; big changes are seen in technological, cultural, economical and social areas. These alterations push the organizations of industry age to transform into information organizations. Therefore, former organizational structures, applied methods and tools, adopted policies and several approaches have the tendency to leave their places to the new concepts. However, one of the biggest changes that the organizations pay attention is the sustainability factor (Barber et al., 2011; Petrini and Pozzebon, 2010; Bansal, 2005; Brundtland Report, 1987) and their change of perspective in this matter (Schrettle et al., 2014; Nidumolu et al., 2009).

In paralel with the economical, social and technological alterations in the world, there have been changes in tourism consumption patterns. Now, instead of demanding sun, sea and sand, tourists individually or in small groups would like to be in nature and see natural and cultural values in their own places. Due to the changes in tourist profiles, consumption patterns and perspective of balanced use and protection of natural and cultural environment, they led to the occurance of some concepts such as ecological tourism, rural tourism or sustainable tourism (Kaypak, 2012: 11; Collier, 2008). Accordingly, societies, organizations, business world and tourism professionals started to pay attention to the concept of sustainability (Kibert, 2016; Mowforth and Munt, 2015; De Lange et al., 2012: 151; Kozak and Kozak, 2011; Santillo, 2007) but how it is perceived by the current tourism and hospitality students and the potential future workforce is a worthwhile topic to research.

In the first part of this study, the theoretical background about the concept of sustainability and sustainability in organizations will be addressed. In the second part, the methodology, findings and the interviews with the undergraduate tourism and hospitality students in a foundation university will be evaluated briefly. In the last part, the conclusion and implications of the research based on the responses, limitations of the study and the future research recommendations will be provided. 


\section{Literature Review}

There are various definitions of sustainability in literature. Currently, it has been estimated that about three hundred definitions of sustainability and sustainable development exist widely within the domain of environmental management and the related disciplines which link with it, either directly or indirectly. Although there has been a debate about the definition of sustainability (Santillo, 2007: 60), in general the following definition is accepted wordwide (PricewaterhouseCoopers, 2012: 9); "Sustainability is providing the daily needs without damaging the needs of future generations. It is defining the business models and life standards that will enable the future generations to survive, without depleting natural resources."

The concept of sustainability holds on the basis of continuity. Continuation is any event or a phenomenon prolonging spontaneously and this continuation is performed by a sustainable action. If something is sustainable, that means it has continuity in its structure. For a sustainable structure, resources should be continuously evaluated, protected consciously and used without overloading the ecosystem or damaging the system (Karaman, 1996: 102). In other words, sustainability is generally seen as a guide for social and economic policymaking in equilibrium with ecological situations (Seghezzo, 2009).

In the late 1960s, due to Western world's approach of industrial based growth that provided an income increase and which lead to the environmental destruction, it brought about the worries in this way of development approach (Schleicher and Strati, 1999). To overcome these worries, it started to be paid more attention to the rise of prosperity level of people, sufficiency in economy, social development and protection of the habitat. To achieve these primary purposes, as Kaypak (2012: 16) and Sohn (1973) mentioned that Stockholm Conference held in 1972 emphasized the carrying capacity of nature, conscious resource use and relationship between economic and social development and nature under the title of sustainable development.

The most commonly used definition of sustainability took place in Brundtland Report which is published in 1987 and it is the outcome of the work by the World Commission on Environment and Development. The report laid out the concept of sustainability as including economic, environmental and social perspectives (Brundtland Report, 1987). The generally accepted definition is; "Sustainable development is the development that meets the needs of the present without compromising the ability of future generations to meet their own needs." (Harris, 2003; WTO, 1998; Brundtland Report, 1987).

From a different perspective, sustainability in the sense of latest tourism trends means sustainable utilization of the natural resources. That is to say, the natural sources should be utilized not only for the present, but also for the future generations (Marriott, 2016; Lu and Nepal, 2009; Collier, 2008; Redclift, 2001; Weale and Williams, 1992). In other words, WTO (1998: 21) defined sustainable tourism development as meeting the needs of present tourists and host regions while preserving and enhancing opportunities for the future and also fulfilling economic, social and aesthetic needs while maintaining cultural integrity, crucial ecological processes, biological diversity and life support mechanisms.

The significance of social issues and the natural environment to societies and organizations has dramatically evolved in the preceding five decades. Corporate managers are becoming aware of the need to expand their goals, beyond the traditional financial expectations. Since the term "sustainability" has entered the corporate world, a rising number of organizations realized the importance of sustainability and stressed the social and environmental goals of their organizations (Hilton, 2016; Intercontinental Hotels Group, 2016; Lawler and Worley, 2012; GRI, 2011; Bansal, 2005) and drew great attention to the sustainable/renewable energy performances of green buildings (Kibert, 2016; Marriott, 2016; GhaffarianHoseini et al., 2013; Dangelico and Pujari, 2010) and innovative perspectives in sustainability (Hertog et al., 2010; Nidumolu et al., 2009; Teece, 2009) within their corporate governance systems (Thomas, 2013).

According to Aktan (2006), the concept of sustainability shows the firms' vision, increases the spirit of trust between the stakeholders, supports the firms' healthy development and growth. The fundamental characteristics that push the organizations to sustainability are; legal conformity, public opinion trust, customers and investor demand. Furthermore, according to PricewaterhouseCoopers (2012), besides the traditional "economy first" point of view, environmental and social perspective should also be included to the sustainability perspective within the organizations and visionary leaders are the ones who think of the activities and ecological balances influencing the community. Wilson (2003: 1) also underlined that sustainable development is a wide concept balancing the need for economic development with the environmental protection and social justice. Sustainability strategy is 
basically formed and applied by three fundamental indicators and their sub-indicators concerning their stakeholders:

Table 1. Sustainability in organizations

\begin{tabular}{|l|l|l|}
\hline \multicolumn{1}{|c|}{ Economy } & \multicolumn{1}{c|}{ Environment } & \multicolumn{1}{c|}{ Social } \\
\hline Corporate governance & Wastes & Human rights \\
\hline Legal relevance & Use of natural resources & Human resource management \\
\hline Rules of business ethics & Biodiversity & Worker health, safety \\
\hline Fraud & Product responsible & Customer health, safety \\
\hline Economic impact on stakeholders & Carbon emissions & Marketing communication \\
\hline Paid taxes & Adaptation to environmental act & Social contribution \\
\hline
\end{tabular}

Source: PricewaterhouseCoopers, 2011

Kolk (2008: 5) emphasized that according to Fortune Global 250 Sustainability Reports, 161 firms prepared a report on sustainability in 2004 and 54.4 percent of the firms prepared separate sustainability reports on economic, environmental and social sustainability. Additionally, 20 percent of them prepared financial reports integrated with sustainability information. Due to the increase in sustainability reports (35 percent in 1998, 45 percent in 2001, 64 percent in 2004) and sustainability indicators (Roca and Searcy, 2012), the leaders and policy makers started to address the issue of sustainability. According to Albino et al. (2009), to respond efficiently and effectively to the environmental sustainability challenge, an essential role can be played by the organizations, through suitable strategies and operations, such as product development and green processes.

In other definitions, according to Porter (1985: 11), sustainability is a concept that indicates a long period of time but as Seviçin (2009: 173) mentioned that the weakest part of the approach is that how much time is considered as long term is not defined. Some other authors believed that sustainability is related with the possibility of being imitated by the competitors. According to Barney (1991: 102), if the advantage continues and still survives despite the imitation efforts of the competitors, this is called as sustainability. What lies under sustainability can also be expressed as continuation of organizational values, good management and strong communication, openness to new ideas, innovativeness, creation of cultural wealth, comprehension of strategy, consciousness of social responsibility, being supportive to human rights, protection of the environment and contribution to the community. For instance, Sarıkaya et al. (2010: 43) addressed four factors influencing sustainability in the organizations; 1. Having the capacity and ability to decrease the risk by preventing environmental pollution and increase profits. 2 . Obtaining a position through technology by having a creative capacity. 3. Having a vision and developing a route map for the future, and 4. Communication with the stakeholders. In relation with Marriott (2016)'s efforts in greening its supply chain, Okumuş (2012) also added that the creation of a value chain among the stakeholders is critical in understanding sustainability and its relation within that chain.

\section{Methodology}

The fundamental purpose of the research is to analyze the level of perception of "sustainability" and to evaluate the current opinions of undergraduate tourism and hospitality students about sustainability and the significance of it in one foundation university in Izmir, Turkey.

In line with the research method and sample characteristics, a qualitative research technique is chosen for this research to explore the concept of sustainability through the interviews. Totally, nine questions are asked to 57 undergraduate tourism and hospitality students who took at least one sustainability course within their education curriculum. Within the research analysis, structured face to face interviews took approximately 15 minutes to analyze in-depth data, to provide as much detail on the topic as possible during that short period of time and finally to collect the required responses. In addition, the structured interview technique makes the participants feel that they have been able to perform at their best and give the interviewers the necessary information they look for (University of Bristol, 2014). Besides the demographic characteristics, interview questions are related with the definition of sustainability, the level of importance given to sustainability by the organizations and tourism industry in Turkey based on the responses, the tendency to work in the tourism industry in future and experience level of participants within industry. The research is inspired by Brundtland Report (1987) and PricewaterhouseCoopers (2011) in which economic, social and environmental characteristics of sustainability are mentioned and the research of Fokiali et al. (2005) in which general sustainability and sustainable tourism questions are researched 
among the students in one high school. Sustainability questions are prepared accordingly. Within these factors, to be able to comprehend the responses of participants will show different perspectives of sustainability.

In this research, according to the identified concepts through the analyzed data, coding method is preferred to be able to form a conceptual structure. Coding is done to the data which are collected from each of the interviewees and the description of codes are expressed under the below topics;

- Meaning of sustainability

- Words describing sustainability

- Attention to sustainability by the organizations and the importance given to sustainability in the tourism and hospitality industry

\section{Main Findings}

Due to 57 responses of undergraduate tourism and hospitality students, the demographic characteristics, the meaning of sustainability, the expressions about sustainability, the attention to sustainability by the firms, the importance of sustainability in tourism industry in Turkey and the tendency to work in the industry, are clearly summarized below.

The demographic factors emphasize that the average age of 57 undergraduate tourism and hospitality students is 23.7. In addition, 51 percent of the respondents is male and 49 percent is female. The mean age of male is 23.4 and the mean age of female is 23.7. The average experience of the respondents is 25 months and 28 respondents (49 percent) have never been abroad and 29 respondents ( 51 percent) who have been abroad represent the average length of stay which is 176 days.

Meaning of Sustainability. Table 2 represents the opinions of respondents about the meaning of sustainability and their weighted percentage. Among 57 respondents who took at least one course related with sustainability within their education curriculum, several expressions are used in defining the concept of sustainability. Among these respondents, 19 (33 percent) of them stated that protecting historical, cultural and natural values, improving and recycling mean sustainability to them. 16 respondents (28 percent) said that sustainability is to exist and continue the ecological system and survive as a firm. 6 of them (10.5 percent) underlined that sustainability is transferring scarce resources, especially energy, to the next generations. Only, 3 respondents (5 percent) expressed that sustainability is success, survival of business, increase of prosperity and economic development. Only 3.5 percent each believed that sustainability means gaining revenue and innovation. Two respondents did not answer the question but 7 percent of the respondents stated several answers such as sensitivity in nature, efficient use, most vital concept for humanity and taking control of consumption. Based on the interviews, collected data analysis showed that the respondents defined the meaning of sustainability from various perspectives. In parallel with the research results of Fokiali et al. (2005), the research outcomes revealed that the respondents are knowledgeable about the sustainability matter which also increases the reliability of the research. Furthermore, some sample responses about the definition of sustainability are stressed as follows;

A 23 year old male believed that sustainability means "Improving and protecting our historical, cultural and natural values. Protecting our water resources, air and heritage and keeping them clean is essential so that others can benefit in the future." A 24 year old female stated that "To me, sustainability means not destroying the environment, natural resources and living organisms, using the scarce resources in a less damaging way efficiently and effectively and transfering them to new generations." 
Table 2. Meaning of sustainability

\begin{tabular}{|l|c|}
\hline Concept of Sustainability & $\begin{array}{c}\text { Percentage of } \\
\text { respondents }(\%)\end{array}$ \\
\hline Improving and protecting historical, cultural and natural values, recycling & 33.3 \\
\hline Continuation (continue to exist, ecological system, continuation of firm) & 28.1 \\
\hline Transferring resources (energy) to next generations & 10.5 \\
\hline Success, continuation of business (increase of prosperity, economic development) & 5.3 \\
\hline Development of job & 5.3 \\
\hline Gaining revenue & 3.5 \\
\hline Innovation & 3.5 \\
\hline No answer & 3.5 \\
\hline Others (sensitivity in nature, efficient use, vital for humanity, control of consumption) & 7.0 \\
\hline
\end{tabular}

Expressions About Sustainability. Table 3 symbolizes the words expressed by 57 undergraduate tourism and hospitality students and their weighted percentage. Among the expressions emphasized by the respondents, 15 (26.3 percent) of them stated that they described sustainability as protection of green, community values and people. In addition, 14 percent each described sustainability as recycling and natural beauty (purity). Additionally, 7 of them (12.3 percent) believed that sustainability is continuation, survival in business, balance between economical, environmental and social factors and 5 respondents ( 8.8 percent) said that it is an ecological balance and a long term activity. Only 7 percent of the respondents expressed that it is future and the increase of consciousness about sustainability. Moreover, 5.3 percent each stated that sustainability is innovation and adding value to whatever activity is performed, quality of service and customer satisfaction. Two respondents (3.5 percent) believed that it is development of the economy (jobs, employment and education). Only, 1.7 percent each expressed sustainability as technology use, staying up-to-date and energy use, money and profitability. In literature, for instance, although Kaypak (2012), Sarıkaya et al. (2010), Brundtland Report (1987) and Sohn (1973) emphasized the carrying capacity of the natural habitat, surprisingly none of the participants addressed the carrying capacity of the nature within the sustainability perspective. Sample responses are mentioned below;

A 23 year old female stated that "Sustainability is protection of natural resources, without depleting resources, providing liveable places and the continuation of biological variety. Profit gain is not the main purpose. Protection of local cultures is essential." A 22 year old male said that "Sustainability is performing at a high level while working, adding value to your job and increasing quality of things you are working on, protecting quality and surviving in business."

Table 3. Mentioned words about sustainability

\begin{tabular}{|l|c|}
\hline Words describing sustainability & Percentage of respondents (\%) \\
\hline Protection (green, values and people) & 26.3 \\
\hline Recycling, renewable & 14 \\
\hline Natural beauty, purity & 14 \\
\hline $\begin{array}{l}\text { Continuation, survival in business, balance between economical, } \\
\text { environmental and social factors }\end{array}$ & 12.3 \\
\hline Ecological balance, long-term & 8.8 \\
\hline Future and consciousness & 7.0 \\
\hline Innovation and adding value & 5.3 \\
\hline Quality of service and customer satisfaction & 5.3 \\
\hline Development of economy, job, employment and education & 3.5 \\
\hline Technology, staying up-to-date and energy & 1.75 \\
\hline Money and profitability & 1.75 \\
\hline
\end{tabular}

Attention of Firms to Sustainability in Turkey. The following question is asked to the respondents so as to understand whether the firms pay attention to sustainability in Turkey. Do firms give importance to sustainability in Turkey? Out of 57 undergraduate tourism and hospitality students, 42 respondents (73.7 percent) believed that firms do not give importance to sustainability in Turkey. However, 15 respondents (26.3 percent) emphasized that 
firms pay attention to the subject of sustainability in Turkey. Based on the interviews, the analysis showed that close to half of the respondents do not believe that firms are conscious about sustainability matters and they neglect the applications of sustainability.

For example, a 23 year old female expressed her opinion as; "In recent years, there has been substantial developments in firms in Turkey. However, they aren't thoroughly conscious about sustainability. Although some firms make plans for long-term and think about the future of society, most firms think about their own interest, live on a daily basis. Traditional methods in business contradict with sustainability." A 24 year old male emphasized that "The consciousness is formed slowly recently but the hotels started using green hotel applications in Turkey. Protecting social values in the society which sometimes lacks, is also a part of comprehending sustainability."

Importance of Sustainability in Tourism Industry in Turkey. The question "How much sustainability is important in tourism industry in Turkey?" is asked to the undergraduate tourism students to comprehend whether sustainability is essential especially for tourism and hospitality industry. During the interviews, out of 57 respondents, 26 people (45.6 percent) underlined that sustainability is very important for the tourism industry. On the other hand, 17 people (29.8 percent) believed that sustainability will gain significance in the near future and 14 people (24.6 percent) said that sustainability isn't seen as an essential ingredient for the tourism and hospitality industry in Turkey.

For instance, a 24 year old male said that "The natural resources aren't unlimited. There has to be consciousness in tourism industry. Firms and employees should know their proper choices, technology, energy management and environment, analyze, plan with proper use of resources. There is densely mass tourism in our country and natural resources are affected by this situation. Protection of them is critical if sustainability matters. However, touristic product diversification such as eco-tourism, green tourism or nature tourism can be provided." Besides, a 22 year old female mentioned that "Sustainability is not that essential. Except the chain hotels, along with their qualified and well-trained personnel, most of the firms pay attention more to profit and revenues."

Tendency to Work in Tourism Industry. The question "Would you like to work in tourism industry in the future?" examines whether the respondents are willing or unwilling to work in tourism and hospitality industry. Out of 57 undergraduate tourism students, 36 of them (63.1 percent) said that they would like to work in the tourism industry, but 20 respondents ( 35 percent) expressed that they would not like to work in the tourism industry and only 1 respondent answered that he might choose to work in the industry. Moreover, half of the respondents who have less than two years of work experience in the tourism industry and have never been abroad are less aware of the sustainability matters than the ones who have been overseas frequently and more than two years of work experience in the industry. Some of the given responses are as follows;

A 22 year old female stated that "Tourism sector is a dynamic sector and to work in it is an intriguing experience. In future, I would like to investigate the tourism sector and prepare the youngsters who would want to work in the industry and look at it from an academic perspective." A 23 year old male stressed that "To communicate with people from different nationalities, serve and please them, satisfy their needs and make them happy is important which will make me happy too." However, a 24 year old female approached the subject negatively and stated that "Although tourism is a developing sector, it is very exhausting, generally your effort is maximum but the return is very low."

In line with the research results of Fokiali et al. (2005), the study findings revealed that the respondents are knowledgeable about the issue of sustainability. Besides, although some studies such as Kaypak (2012), Sarikaya et al. (2010), Brundtland Report (1987) and Sohn (1973) addressed the carrying capacity of the environment, surprisingly none of the respondents mentioned the carrying capacity of the nature within the sustainability perspective. Based on the interviews, the analysis indicated that close to half of the respondents don't believe that firms are conscious about sustainability and its real applications. For example, as Hertog et al. (2010) and Nidumolu et al. (2009) expressed the significance of innovative perspectives in sustainability, only a few respondents related innovation with the concept of sustainability. Although, there are entrepreneurial activities related with sustainability in the tourism industry in Turkey (Ministry of Culture and Tourism, 2007), astoundingly, a quarter of the respondents said that sustainability is not seen as an pivotal ingredient for the tourism and hospitality industry in Turkey. Fifty percent of the respondents who have less than two years of work experience in the service industry and have never been overseas are less aware of the sustainability issues than the ones who have more than two years of work experience in the industry and been abroad often. In addition, one third of the respondents implied that they don't have the tendency to work in the tourism industry. The critical approach is to 
show them how they can benefit from the tourism and hospitality industry along with the value creations and sustainability trainings within their business environment. During the interviews, in general, environmental and economic factors of sustainability are more emphasized than the social characteristics of sustainability, as Pirnar (2016) mentioned some of the social factors such as sustainable local projects and voluntary support of hotel chains benefiting low income communities.

\section{Conclusion and Further Research}

The fundamental purpose of this research was to analyze the level of perception of sustainability and to evaluate the current opinions of undergraduate tourism and hospitality students about sustainability in a foundation university in Izmir, Turkey. Due to the research outcomes, the vast majority of the respondents believed that firms in Turkey do not pay attention to the issue of sustainability. However, close to half of the respondents said that sustainability is very important for the tourism and hospitality industry. Only one third of the respondents believed that it will gain importance in the near future and a quarter of the participants stated that sustainability is not seen as an essential ingredient for the tourism industry in Turkey. In addition, considering aptly two years of work experience in average in the tourism and hospitality industry, close to half of the respondents have never been abroad and missed the opportunity of perceiving sustainability, related applications and activities from a different angle. In literature, although Kaypak (2012), Sarıkaya et al. (2010), Brundtland Report (1987) and Sohn (1973) stressed the carrying capacity of nature, interestingly none of the respondents mentioned the carrying capacity of the environment within the sustainability perspective. Due to these outcomes, the awareness of sustainability needs to be improved in the near future by the application of influencial sustainable programs, continuous staff trainings, effective communication with the industry leaders and policy makers, creation of sustainability standards, educational and sustainable activities in schools and organizations. The studies in literature also support this need and the change of view in this matter (Kibert, 2016; Mowforth and Munt, 2015; Schrettle et al., 2014; De Lange et al., 2012; Kozak and Kozak, 2011). The results might also help update the educational curriculum (Deale and Barber, 2012; Barber et al., 2011) as well. In other words, thinking of how to make the concept of sustainability a major ingredient for the tourism and hospitality industry is crucial in embracing sustainable perspectives.

In terms of looking at the perception levels in sustainability, there are various levels of perceived sustainability depending on the interviewed participants. However, more than half of the undergraduate tourism and hospitality students mainly stated that sustainability means protecting historical, cultural and natural values, improving and recycling, existing and continuing the ecological system and staying alive as a firm. But specifically protection of the green environment, cultural, social and society values, natural beauty and recycling outweigh gaining revenue as a firm and having a profitable business. Surprisingly, being innovative and adding value to what you are doing is less considered in terms of describing sustainability. On the other hand, around 10 percent of the participants caught the definition of sustainability (Brundtland Report, 1987; PricewaterhouseCoopers, 2012) partially who mentioned the balance between economical, social and environmental sustainability in reaching your main goal. In addition, regarding the varying perceptions of sustainability according to the experience level of the sample, an important insight is offered in the research. The undergraduate tourism students with more than 2 years of work experience in the tourism industry and who have been overseas, evaluate or assess sustainability and its applications better than the ones with less work experience than 2 years in the tourism industry and who have never been abroad.

Considering the previous responses and discussion about sustainability, more than half of the respondents said that they would like to work in the tourism and hospitality industry, but on the other hand, one third of them emphasized that they would not like to work in the tourism industry. The crucial point is to find ways to let them gain their confidence to work in this live industry and show them how they can actually benefit from the industry along with the sustainability trainings and value additions to the work environment, etc. Working in the tourism industry should be appealing either to the industry professionals or to the potential workforce and the industry leaders should work towards this purpose. In tourism literature, however Jenkins (2001) stated that there are reports that the industry has a poor image in the eyes of hospitality students and the industry may have greater difficulty attracting, recruiting and retaining quality staff. According to the study of Sar1 and Nazlı (2014), long working hours, working conditions (stressful environment, workload and physical toughness), low wages and salaries, lack of holidays, lack of caring employees and professionalism influence employee and potential workforce decisions to stay in the tourism and hospitality industry. 
At this point, organizations and the tourism industry in Turkey should understand how economical, social and environmental characteristics are considered in sustainability efforts, how the concept of sustainability works and helps the organizations sustain their fundamental and subsidiary activities and create various perspectives to stay in the business environment. In other words, the better the industry leaders, policy makers or industry professionals know the economical, social and environmental considerations or perspectives and convey these information to their environment, the stronger their sustainable strategies will become and the more they can influence their value chain and the stakeholders.

The research comes with its limitations. The sample size consists of only 57 interviewed undergraduate tourism and hospitality students from one foundation university situated in Izmir. It was an exploratory research to comprehend the respondent's general perception of sustainability and the significance of it in tourism and hospitality industry in a specific region. Moreover, time was limited for the process of data collection which led to a limited number of sample size for the research.

For future research and analysis, a greater sample size with a quantitative analysis can strengthen the findings and results and enliven different perspectives of sustainability. Tourism related firms' (travel agencies, tour operators, hotels, marinas, associations and industry professionals) perception of sustainability and its dimensions and depending on these dimensions, exploration of different point of views can be analyzed. The research basically gives an idea about the perception of sustainability for future analysis and it may help update the offered courses or curriculum in academia as well. 


\section{REFERENCES}

Aktan, C. C. (2006). Kurumsal Şirket Yönetimi - Sermaye Piyasası Kurulu, Kurumsal Araştırmalar Serisi No:4, Ankara.

Albino, V., Balice, A., Dangelico, R. M. (2009). "Environmental strategies and green product development: an overview on sustainability-driven companies". Business Strategy and the Environment, 18 (2), 83-96.

Bansal, P. (2005). "Evolving sustainably: A longitudinal study of corporate sustainable development". Strategic Management Journal, 26 (3), 197-218.

Barber, N., Deale, C., Goodman, R. (2011). "Environmental sustainability in the hospitality management curriculum: Perspectives from three groups of stakeholders". Journal of Hospitality \& Tourism Education, 23 (1), 6-17.

Barney, J. B. (1991). "Firm Resources and Sustained Competitive Advantage”. Journal of Management, 17, 99120.

Brundtland Report (1987). Our Common Future. http://www.bneportal.de/fileadmin/unesco/de/Downloads/ Hintergrundmaterial_international/Brundtlandbericht.File.pdf?linklisted=2812, Accessed on: 28.12.2015.

Collier, R. (2008). Sustainable Tourism for Dummies. England: John Wiley \& Sons, Ltd.

Dangelico, R. M., Pujari, D. (2010). "Mainstreaming green product innovation: Why and how companies integrate environmental sustainability". Journal of Business Ethics, 95 (3), 471-486.

Deale, C. S., Barber, N. (2012). "How important is sustainability education to hospitality programs?". Journal of Teaching in Travel \& Tourism, 12 (2), 165-187.

De Lange, D. E., Busch, T., Delgado-Ceballos, J. (2012). "Sustaining sustainability in organizations". Journal of Business Ethics, 110 (2), 151-156.

Fokiali, P., Xanthakou Y., Tatlıdil R., Tatlıdil E., Kaila M. (2005). “Tourism and Sustainable Development Strategies in Rhodes: The Awareness of the Local Societies”, X. European Ecological Congress, Organized by European Ecological Federation Turkish Ecological Society, Ege University Center for Enviromental Studies.

GhaffarianHoseini, A., Dahlan, N. D., Berardi, U., Makaremi, N., GhaffarianHoseini, M. (2013). "Sustainable energy performances of green buildings: A review of current theories, implementations and challenges". Renewable and Sustainable Energy Reviews, 25, 1-17.

GRI (2011). A new phase: The growth of sustainability reporting. GRI's Year in review 2010/11. Amsterdam: Global Reporting Initiative.

Harris, J. M. (2003). "Sustainability and Sustainable Development”. International Society for Ecological Economics, 1-12.

Hertog, P. D., Aa, W. V. D., Jong, M. W. D. (2010). "Capabilities for managing service innovation: towards a conceptual framework". Journal of Service Management, 21 (4), 490-514.

Hilton Worldwide (2016). Our Approach - Executive Statement. http://cr.hiltonworldwide.com/approach/, Accessed on: 11.03.2016.

Intercontinental Hotels Group (2016). IHG Green Engage System. http://www.ihgplc.com/index.asp?pageid=742, Accessed on: 01.03.2016.

Jenkins, A. K. (2001). "Making a career of it? Hospitality students' future perspectives: an Anglo-Dutch study". International Journal of Contemporary Hospitality Management, 13 (1), 13-20.

Karaman, A. (1996). Sürdürülebilir Turizm Planlaması İçin Ekolojik Bir Çerçeve, Sürdürülebilir Turizm; Turizm Planlamasına Ekolojik Yaklaşım, 19. Dünya Şehircilik Günü Kolokyumu, Mimar Sinan Üniversitesi, İstanbul.

Kaypak, Ş. (2012). "Ecological Tourism and Sustainable Rural Development”. KMÜ Sosyal ve Ekonomik Araştırmalar Dergisi, 14 (22), 11-29.

Kibert, C. J. (2016). Sustainable construction: green building design and delivery. John Wiley \& Sons.

Kolk, A. (2008). "Sustainability, Accountability and Corporate Governance: Exploring Multinationals' Reporting Practices", Business Strategy and the Environment, 18, 1-15.

Kozak, M., Kozak, N. (Eds.) (2011). Sustainability of Tourism: Cultural and Environmental Perspectives. Cambridge Scholars Publishing.

Lawler, E. E., Worley, C. G. (2012). "Designing organizations for sustainable effectiveness". Organizational Dynamics, 41, 265-270. 
Lu, J., Nepal, S. K. (2009). "Sustainable tourism research: An analysis of papers published in the Journal of Sustainable Tourism”. Journal of Sustainable Tourism, 17 (1), 5-16.

Marriott International (2016). Our Environment Goals. http://www.marriott.com/corporate-social-responsibility/ corporate-environmental-responsibility.mi, Accessed on: 15.08.2016.

Ministry of Culture and Tourism (2007). Tourism Strategy of Turkey - 2023. https://www.kultur.gov.tr/Eklenti/ 43537,turkeytourismstrategy2023pdf.pdf?0\&_tag1=796689BB12A540BE0672E65E48D10C07D6D AE291, Accessed on: 16.08.2016.

Mowforth, M., Munt, I. (2015). Tourism and sustainability: Development, globalisation and new tourism in the third world. Routledge.

Nidumolu, R., Prahalad, C. K., Rangaswami, M. R. (2009). "Why sustainability is now the key driver of innovation". Harvard Business Review, 87 (9), 56-64.

Okumuş, K. (2012). Yeni Bir İşletme Anlayış1: Kurumsal Sürdürülebilirlik, Accessed on: http://www.kriterdergisi.com/haber.php?sayi=39\&id=882, 26.12.2015.

Petrini, M., Pozzebon, M. (2010). "Integrating Sustainability into Business Practices: Learning from Brazilian Firms". Brazillian Administrative Review, 7 (4), 362-378.

Pirnar, I. (2016). The Routledge Handbook of Hotel Chain Management: Economic impacts of hotel chains on host destination, Eds: Maya Ivanova, Stanislav Ivanov \& Vincent P. Magnini, Routledge, London and New York.

Porter, M. E. (1985). Competitive Advantage: Creating and Sustaining Superior Performance, New York: The Free Press.

PricewaterhouseCoopers (2012). Türk İş Dünyası'nda Sürdürülebilirlik Uygulamaları Değerlendirme Raporu 2011. https://www.pwc.com.tr/tr/publications/arastirmalar/pdf/pwc_surdurulebilirlik_raporu-2012.pdf, Accessed on: 02.01.2016.

PricewaterhouseCoopers (2011). Etkin Sürdürülebilirlik Raporlaması 5 Aralık 2011. https://www.okul.pwc.com.tr /images/uploadfile/content/634589620080864656.pdf, Accessed on: 03.01.2016.

Redclift, M. (2001). "Environmental security and the recombinant human: Sustainability in the twenty-first century”. Environmental Values, 10, 289-299.

Roca, L. C., Searcy, C. (2012). “An analysis of indicators disclosed in corporate sustainability reports”. Journal of Cleaner Production, 20 (1), 103-118.

Santillo, D. (2007). "Reclaiming the Definition of Sustainability". Environmental Science and Pollution Research, 14 (1), 60-66.

Sarı, Ö. F., Nazlı, M. (2014). “A Qualitative Study on the Pride Notion of Tourism and Hospitality Students in Turkey”. International Journal of Contemporary Economics and Administrative Sciences, 3 (3-4), 47-67.

Sarıkaya, M., Erdoğan, M., Kara, Z. F. (2010). “İnternet Ekonomisi ve Kurumsal Sürüdürebilirlik”, Eskişehir Osmangazi Üniversitesi İIBF Dergisi, 5 (2), 43.

Schleicher-Tappeser, R., Strati, F. (1999). Progress Towards Sustainable Regional Development. A Review of Results from the EU Research Programme on Human Dimensions of Environmental Change, Luxembourg Office for Official Publications of the European Communities, http://sustainablestrategies.eu/wp-content/ uploads/2013/12/insured_en.pdf, Accessed on: 05.01.2016.

Schrettle, S., Hinz, A., Scherrer-Rathje, M., Friedli, T. (2014). "Turning sustainability into action: Explaining firms' sustainability efforts and their impact on firm performance”. International Journal of Production Economics, 147, 73-84.

Seghezzo, L. (2009). "The five dimensions of sustainability”. Environmental Politics, 18 (4), 539-556.

Seviçin, A. (2009). “Sürdürülebilir Rekabet Üstünlüğ̈̈”. ZKÜ Sosyal Bilimler Dergisi, 5 (10), 173.

Sohn, B. L. (1973). "The Stockholm Declaration on the Human Environment”. The Harvard International Law Journal, 14 (3), 423-515.

Teece, D. J. (2009). Dynamic Capabilities and Strategic Management: Organizing for Innovation and Growth, Oxford University Press, Oxford.

Thomas, C. C. (2013). Corporate Governance And Sustainability: A Time For Reassessment. 13th International Conference on Corporate Governance \& Sustainability, London.

University of Bristol, (2014). Human Resources, http://www.bristol.ac.uk/hr/resourcing/practicalguidance/ selection/interviewtechniqe, Accessed on: 17.02.2016.

Weale, A., Williams, A. (1992). "Between economy and ecology? The single market and the integration of 
environmental policy”. Environmental Politics, 2 (1), 45-63.

Wilson, M. (2003). "Corporate Sustainability: What is it and where does it come from?" Ivey Business Journal, March/April, pp.1-5, www.unescap.org/tid/ publication/indpub2565_chap1.pdf, Accessed on: 22.11.2015.

WTO (1998). Guide for Local Authorities on Developing Sustainable Tourism. World Tourism Organization, Madrid. 


\section{APPENDIX}

\section{Interview Questions}

Dear Participant,

The following questions are prepared for the purpose of an academic research and the questions are designed to understand the respondent perspective of the concept of sustainability and the significance of it in Turkey. The identity information is not required and the gathered information will not be used except this research. Thank you very much for your sincere responses in advance.

\section{Sustainability}

1. What does the concept of sustainability mean to you?

2. With what words or expressions can you describe the concept of sustainability?

3. Do organizations give importance or pay attention to sustainability issues in Turkey? How much do you agree or disagree on this matter?

4. How much important is sustainability in tourism and hospitality industry in Turkey? What is your point of view on this issue?

5. Would you like to work in the service industry in the near future? Why or why not? Can you explain your line of reasoning.

\section{Demographic Characteristics}

6. How experienced are you in the tourism and hospitality industry? Mention it in months or years.

7. Have you ever been overseas? If yes, for how long have you been abroad? State it in days.

8. What is your gender?

9. What is your age? 